\title{
41 天井懸架型顕徽鏡の移設と振動について
}

中田精三, 中谷 博, 高階雅紀, 上山博史, 梅下浩司, 河井敏博, 富田敏司，越智隆弘（大阪大手術部）

マイクロ手術の増加に伴い顕徵鏡下手術は増加傾向 にあるが，最近に打ける建築物の構造から振動が問題 となっいる。

1993年の病院移転時には旧病院における顕微鏡の振 動問題を考慮し，移転時の建物設計段階で施設掛と相 談を重ね, 先に十分と考えられる防震設備を行い 4 台 の天井懸架型顕微鏡を設置した。移転時の顕微鏡備兄 付け時の振動测定では予想通り問題はなかったが，診 療開始後に振動が疑われ尃門䇲者に振動測定を依頼し た. その結果，眼科用の手術顕微鏡では手術に支障が あるとの判断から，增設のためとして架台を設置して あった少し振動の少ない隣室に移動した．この経緯に ついてはすでに報告した。

今回，手術室の効率的な利用を考える上で，眼科用 天井懸架型顕微鏡の移設が可能かどらかを検討するこ
とになり，現在使用している手術室から離れた 3 手術 室での顕微鏡設置可能と考えられるシーリングコラム および無影灯の架台を対象として振動測定を行った。 各測定点での X, Y, Z方向の最大振幅值は現在使用 している手術室の最大振幅と大きな相違は認められな かったまた，振動変位量分析結果のグラフを比較し てもほぼ同様の振動形態を示していた，振動としては 建物全体の振動，スラブ面の振動，顕微鏡全体の振動 などを考慮する必要があるが，振動測定結果から実際 の視覚的にみた顕微鏡下の像での振動を予測すること は困難なことがある.今回の测定部位での比較では移 設は可能とる考えられるが，現状の振動を考慮して移 設すべきかどらかを更に検討している.

今回, 以前に行った振動調查結果と比較し，この振 動の現状につき報告する。

\section{2 体液中の高反応性物質の簡易測定方法の開発に関する研究}

高島征助, 谷原正夫（岡山大地域共同研究センター）, 鈴木 章, 稲葉 繁 (日本歯科大高踰者歯科),

青山幸生, 大江容子, 浅利 遥（東邦大第 2 麻酔科学教室）
〔はじめに〕ヒトの体液（血液, 唾液など）中には生 体防御作用を有するもの，それとは逆に病因物質とな るむのなど極めて多数の成分が存在し，しかもそれら の濃度範囲はgオーダーから pg オーダーまでと極め て広い.

演者らはとくに疾病の予防法の指標となるよらな体 液中の低濃度の反応性物質の高感度の簡易迅速測定法 を開発中である。

本報では唾液のペルオキシダーゼ (POD) 活性と分 子内に安定ラジカルを有するジフニルピクリルヒド ラシル (DPPPH) との反応性について相関性について 検討した結果，興味ある結果が得られたので報告する: [実験方法]

1）検体：日本歯科大学高齢者歯科医局員12名から採 取

2）唾液の反応性物質の測定方法

(1) POD 活性の測定法 : -30 C で保存した唾液を 37
Cで速やかに解凍して，各検体を PBS (0.15 モルの $\mathrm{NaCl}$ を含む10ミリモルのリン酸塩楥衝液, $\mathrm{pH}: 7.4$ ) で20倍に希釈し， $100 \mu l$ ずつ96穴プレートに分注した。 各ウェルに $10 \mu l$ の POD 基賀溶液を添加して $37 \mathrm{C} に$ て30分間インキュベートした後の各ウェルの 405, 490 $\mathrm{nm}$ の吸光度の差を測定した（1検体につき 6 回測定）. (2) $\mathrm{DPPH}$ 反応性の測定法 : $4 \times 10^{-5} \mathrm{~g} / \mathrm{m} l$ の DPPH/ $\mathrm{MeOH}$ 溶液, $4 \sim 5 \mathrm{~m} l$ に検体を $0.3 \sim 1.0 \mathrm{~m} l$ 添加し てタッチミキサーで激しく摜拌し，室温で 5 分間放固 した後可視部吸収スペクトルの $510 \mathrm{~nm}$ 付近の極大吸 収位置の吸光度を測定した。

〔測定結果〕検体によっては DPPH/MeOH 溶液の赤 紫色をほぼ完全に消失させるものもあった。この色は DPPH のラシカルに起因するものであり，唾液中に このラジカルと反応する物質が存在することを示唆し ている. POD 活性〜DPPH 褪色性の間には負の相 関関係が成立した。 